\title{
From San Francisco to Tōhoku - 111 yr of continuous earthquake recording in Göttingen
}

\author{
H. Steffen ${ }^{1,2}$, W. Brunk ${ }^{2}$, M. Leven ${ }^{3,2}$, and U. Wedeken ${ }^{2}$ \\ ${ }^{1}$ Lantmäteriet, Lantmäterigatan 2c, 80182 Gävle, Sweden \\ ${ }^{2}$ Wiechert'sche Erdbebenwarte Göttingen e.V., c/o Wolfgang Brunk, Gottfried-August-Bürger-Straße 30, \\ 37130 Gleichen-Wöllmarshausen, Germany \\ ${ }^{3}$ Institut für Geophysik, Georg-August-Universität Göttingen, Friedrich-Hund-Platz 1, \\ 37077 Göttingen, Germany
}

Correspondence to: H. Steffen (holger-soren.steffen@1m.se)

Received: 26 August 2013 - Revised: 16 December 2013 - Accepted: 21 December 2013 - Published: 7 January 2014

\begin{abstract}
In 1902, the so-called Erdbebenhaus (earthquake house) was built in the garden of the Institute of Geophysics of the University of Göttingen to host and protect the very sensitive and fragile seismographs designed by Emil Wiechert. These instruments were the standard at their time, and they are still in operation today, documenting $111 \mathrm{yr}$ of almost continuous seismological observations. Since 2005, the observatory is owned by the Wiechert'sche Erdbebenwarte Göttingen e.V. (Wiechert's earthquake observatory in Göttingen, registered society). This society aims at extending the observational record and protecting the observatory as a cultural heritage.

In this paper we review the history of the observatory in the last $111 \mathrm{yr}$. Special attention is given to the developments in the last decade, when the observatory and further historic buildings and instruments changed ownership. Due to the efforts by the society, the observatory is still running now and open to the public. In addition, it is a part of the German Regional Seismic Network and, thus, observations can be used for scientific investigations.
\end{abstract}

\section{Introduction}

A new discipline in sciences emerged in the 19th century: geophysics. It focused, but not exclusively, on the investigation of the Earth using principles from physics to characterize it in space and time. Although geophysics-like studies had started much earlier, the developments in the 19th century led to its consolidation in science globally.

In the history of geophysics as well as in other sciences, there are many contributors to major steps forward. In geophysics many discoveries and inventions are intrinsically tied to Emil Wiechert, director of the world's first Institute of Geophysics in Göttingen (Schweitzer, 2003). Due to his initiative, an observatory was built to observe seismic waves with sensitive instruments. This observatory still exists today, providing a $111 \mathrm{yr}$-long record of almost continuous seismological observations. It is known as the Wiechert'sche
Erdbebenwarte and is now an appointed cultural heritage in Germany.

In the following, we illustrate the history of the observatory. In particular, we summarize the developments since 2004, when after more than $100 \mathrm{yr}$ of steady and almost untroubled lifetime, the observatory was endangered due to relocation of the institute. The next section introduces the work of Emil Wiechert in Göttingen to construct the observatory and its instruments. This is followed in Sect. 3 by a brief overview of a century of observations and further developments at the institute. Sections 4-6 describe the activities in the last decade to save, protect and maintain the observatory. Finally, we briefly summarize and outline future activities. We note that we will use the German word Erdbebenwarte in the text when we refer to the observatory as a whole, and Erdbebenhaus when referring to the building. 


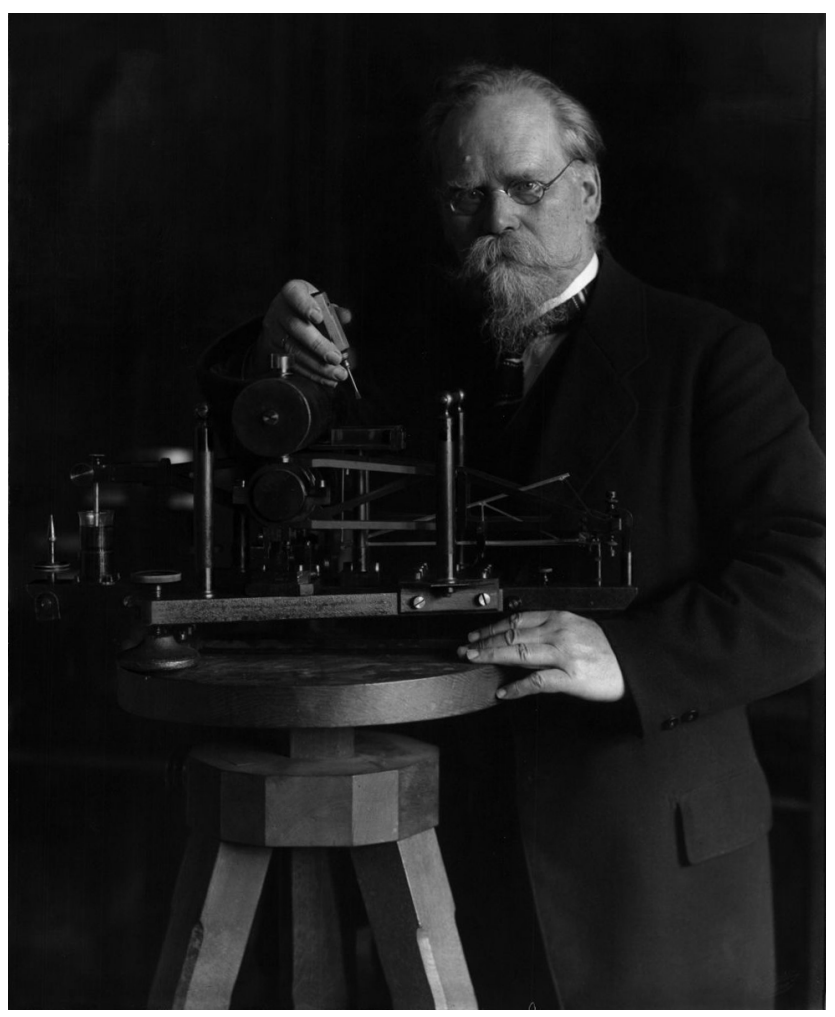

Figure 1. Emil Wiechert (1861-1928). Undated picture (taken by A. Schmidt) property of the Institute of Geophysics, Georg August University Göttingen.

\section{Emil Wiechert, the Institute of Geophysics and the Erdbebenhaus in Göttingen}

A large number of contributions are available about the life and scientific work of Emil Wiechert. A complete biography would be beyond the scope of this paper, therefore, we mainly summarize his contributions to geophysics and the observatory in Göttingen. In the following we rely, if not otherwise stated, on the publications by Wiechert (1906), Gutenberg (1928), Schröder (1982), Mulligan (2001) and Schweitzer (2003). For more information about Wiechert, i.e. his contributions to physics, we refer the interested reader to the literature referenced in this section as well as other references cited therein. A comprehensive list of Wiechert's publications can be found in Hennings and Ritter (2003).

Emil Wiechert (Fig. 1) was born on 26 December 1861 in Tilsit (today Sovetsk) in the Province of Prussia ${ }^{1}$ (today Kaliningrad Oblast, Russia). From 1891 on, he studied sciences with special focus on physics at the Albertus University in Königsberg (today Kaliningrad), eventually complet-

\footnotetext{
${ }^{1}$ It is often mentioned that Wiechert was born in the Province of East Prussia. This is a mistake. From 1824-1878, East Prussia was combined with West Prussia to form the Province of Prussia in the Kingdom of Prussia. In 1878, they were reestablished as separate provinces.
}

ing his Ph.D. in February 1889 with a thesis Über elastische Nachwirkung (On the elastic aftereffect). His studies also covered mathematics, astronomy, geology and philosophy. In October 1890, he completed his habilitation (venia legendi) and he received the title Professor of Physics in 1896.

During those years, he made many substantial physicsrelated discoveries. In 1896/1897, for example, he was one of the first to discover that cathode rays are particle streams. $\mathrm{He}$ correctly measured the ratio between the mass and the charge of these particles. However, he did not conclude that these low-mass particles with respect to hydrogen actually represented a new elementary particle, the electron. Besides his studies and investigations in the field of physics, he was also interested in geophysical topics. In 1896, he published for the first time his idea of an iron core inside the Earth (Wiechert, 1896), a view that was in parts confirmed by many other scientists in later studies.

In 1897, Wiechert was offered a position as a so-called Assistent in the group for theoretical physics at the Institute of Physics of the University of Göttingen. He followed Woldemar Voigt (1850-1919), whom he knew from Königsberg, and who led the group. It turned out that Wiechert arrived at a time of change in the physics-related institutes in Göttingen. Some months after his arrival in May 1897, the head of Department B of the Astronomical Institute, Ernst Schering (1833-1897), died, and the university began reorganizing this institute based on the ideas of Schering.

In 1868, the Astronomical Institute was split into two departments: Department A for practical astronomy and Department B for theoretical astronomy, geodesy and geomagnetism. However, Schering wanted to create a leading institute for geomagnetism only, but failed to split this part from Department B during his life. Now after his death in 1897, it was divided into two new professorships, for theoretical astronomy and for geophysics. The latter was meant to be the head of the geomagnetic observatory. (The third part of the former Department B, geodesy, was still part of lectures in Göttingen, but mainly as part of the Institute for Applied Mathematics and Mechanics. However, Wiechert also taught courses in geodesy as part of his teaching load.)

Wiechert was nominated as Professor of Geophysics on 28 January 1898, which was the second time in the world that the word geophysics was used to name a professorship. (The first Professor of Geophysics was Maurycy Pius Rudzki (1862-1916) at the Jagiellonian University in Kraków). On 1 April 1898, he became responsible for the geomagnetic observatory. Already a few weeks later on 2 July 1898, the observatory was officially renamed to Institut für Geophysik (Institute of Geophysics), being the first of its kind in the world. The renaming, initiated by Wiechert and strongly supported by his colleagues, was necessary as the institute was not focused on geomagnetism only, but also on all kinds of physics related to the Earth.

In the beginning Wiechert appeared to be not overly enthusiastic about taking over the new institute, being forced to 


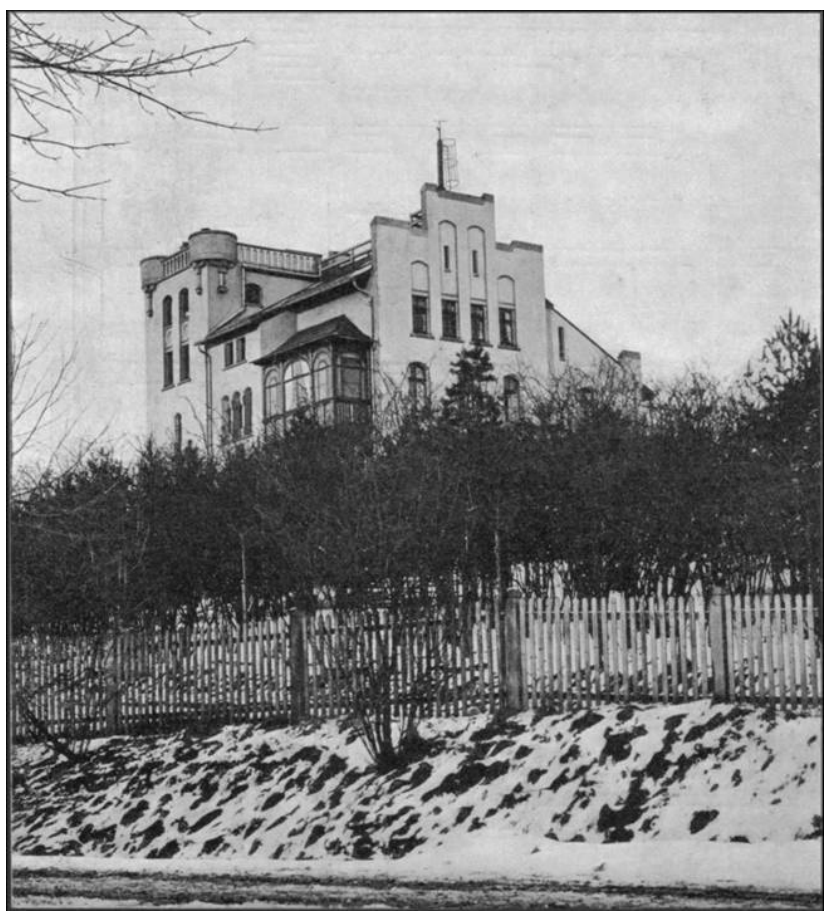

Figure 2. The Institute of Geophysics circa 1905. Undated picture taken and slightly modified from Wiechert (1906).

limit his scientific work to a smaller area than his beloved physics. In addition, the new institute was supposed to be based on geomagnetism research only. Nonetheless, he wanted to branch into all the fields of geophysics. He then enthusiastically followed this idea supported by his colleagues, the renaming of the institute, and new buildings (see below). Due to limitations in staff - it was only the director (Wiechert), an assistant and the housekeeper - the main focus eventually turned out to be seismology (or seismics, as it was called), in addition to limited research in meteorology and geomagnetism.

The institute's development was notably supported, i.e. by Felix Klein (1849-1925). In spring 1898, plans already existed to build a new building solely for the institute. Construction began in 1899 on the Hainberg east of Göttingen's city center. Several smaller huts for experiments as well as a main building were built. In fall 1901, the institute moved into this new building (Fig. 2), which was oriented towards the north. Wiechert lived here on the second floor from 1904 until his death in 1928 (Oberdiek, 2002). One has to note that in the beginning both public electricity as well as public water supply were not available on the Hainberg (Oberdiek, 2002). Hence, a gas engine delivered electricity and rain water was captured in a cistern (Oberdiek, 2002).

At the turn of the century the development and construction of the first horizontal pendulums in Göttingen were made. Wiechert received a dedicated building, the Erdbebenhaus (earthquake house, Fig. 3), to house them, which is

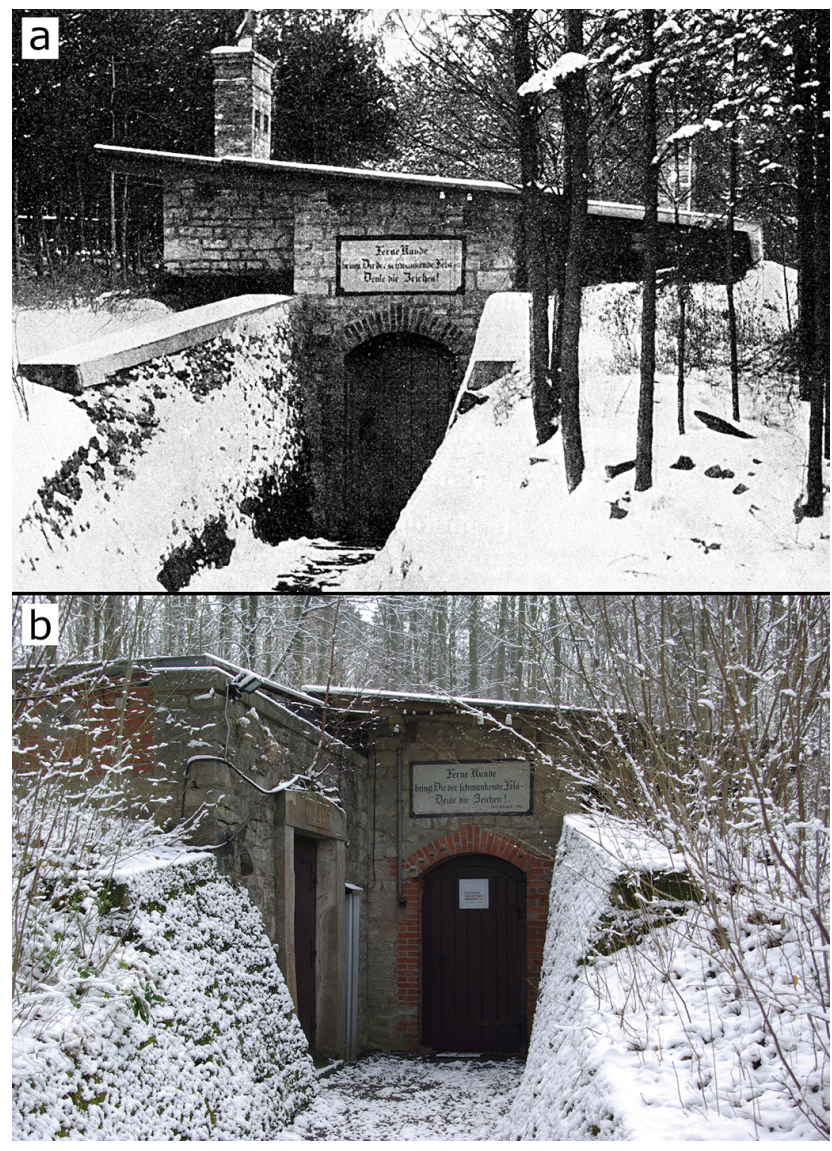

Figure 3. (a) Altes Erdbebenhaus circa 1905. The inscription by Emil Wiechert (Fig. 4) is found above the entrance. Undated picture taken and slightly modified from Wiechert (1906). (b) Erdbebenwarte with altes Erdbebenhaus and neues Erdbebenhaus (building to the left) in 2008. Photo: Udo Wedeken.

nowadays known as altes Erdbebenhaus (old earthquake house). It was built in 1902 in the garden in close vicinity of the institute's building, partly hidden in the underground of the surrounding hilly area. It was originally equipped with a vestibule and the instrument or seismometer room. Later, in 1970, a room for the smoking device for covering paper with soot (so-called smoked paper) was included in the back. Above the entrance one can still find Wiechert's inscription from 1902: "Ferne Kunde bringt Dir der schwankende Fels : Deute die Zeichen!" (The trembling rock bears tidings from afar -: Read the signs!; Fig. 4).

Three mechanical seismometers were installed in the following years in the seismometer room; an astatic horizontal, a vertical and a $17 \mathrm{t}$ horizontal pendulum (filled with baryte). The astatic horizontal pendulum was built in 1900 and observations in the new building started in 1902 (Schreiber, 2000). The official start for continuous observations was 1 January 1903. The vertical pendulum was built in the years 1904 and 1905 and has been recording since then. Construction of the $17 \mathrm{t}$ pendulum began in 1904 (Schreiber, 2000). The 


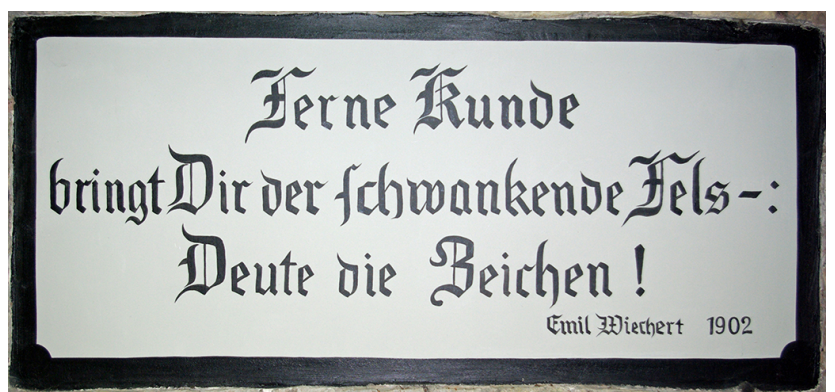

Figure 4. The inscription by Emil Wiechert: The trembling rock bears tidings from afar -: Read the signs! Photo: Udo Wedeken.

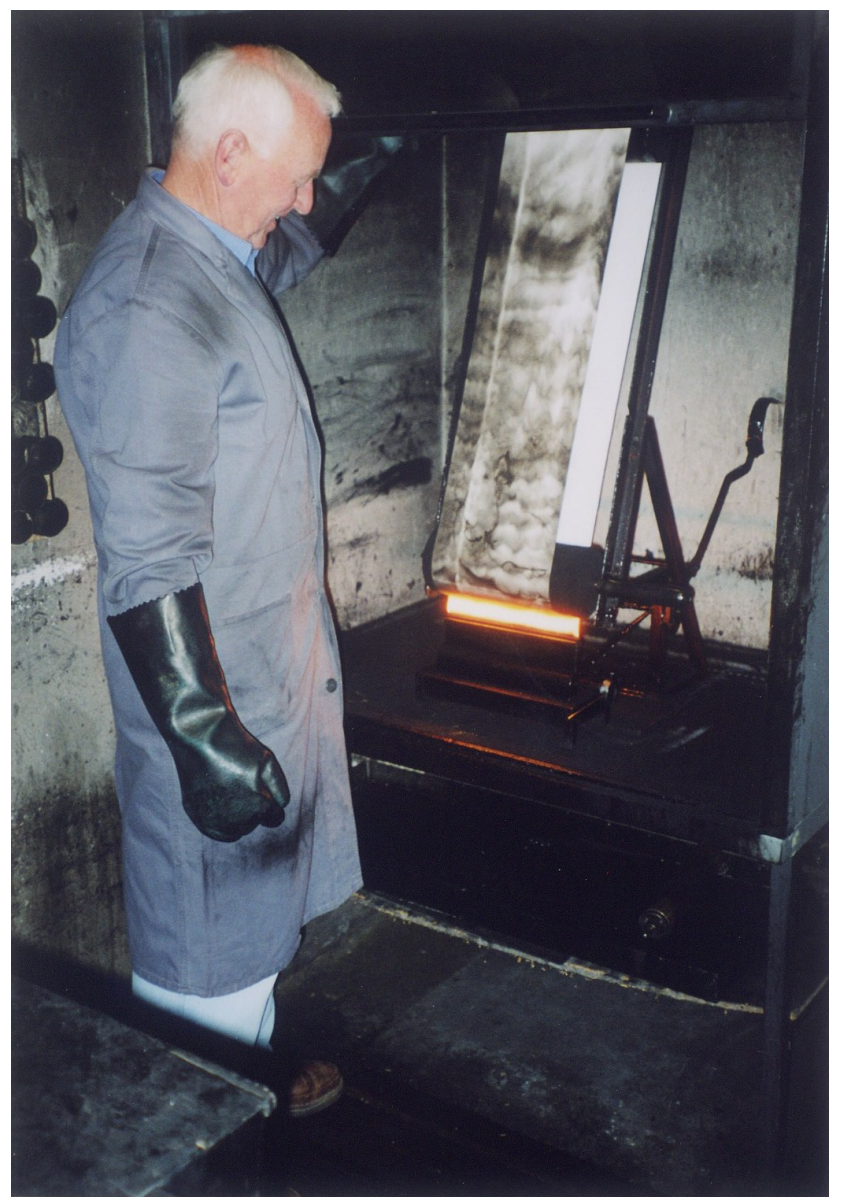

Figure 5. Smoking the paper. Photo: Holger Steffen.

north-south component has been recording since 1907 (although first observations were made in 1905), the east-west component since 1932 (Schreiber, 2000). All instruments are air-damped, invented and tested by Wiechert in 1898/1899.

The basic idea of these instruments is an inverted pendulum, hung up on air-damped springs to avoid eigenoscillations by the pendulum (Wiechert, 1903). The relative motion of the pendulum's mass with respect to the ground, e.g. due to an earthquake, is resolved into perpendicular com-

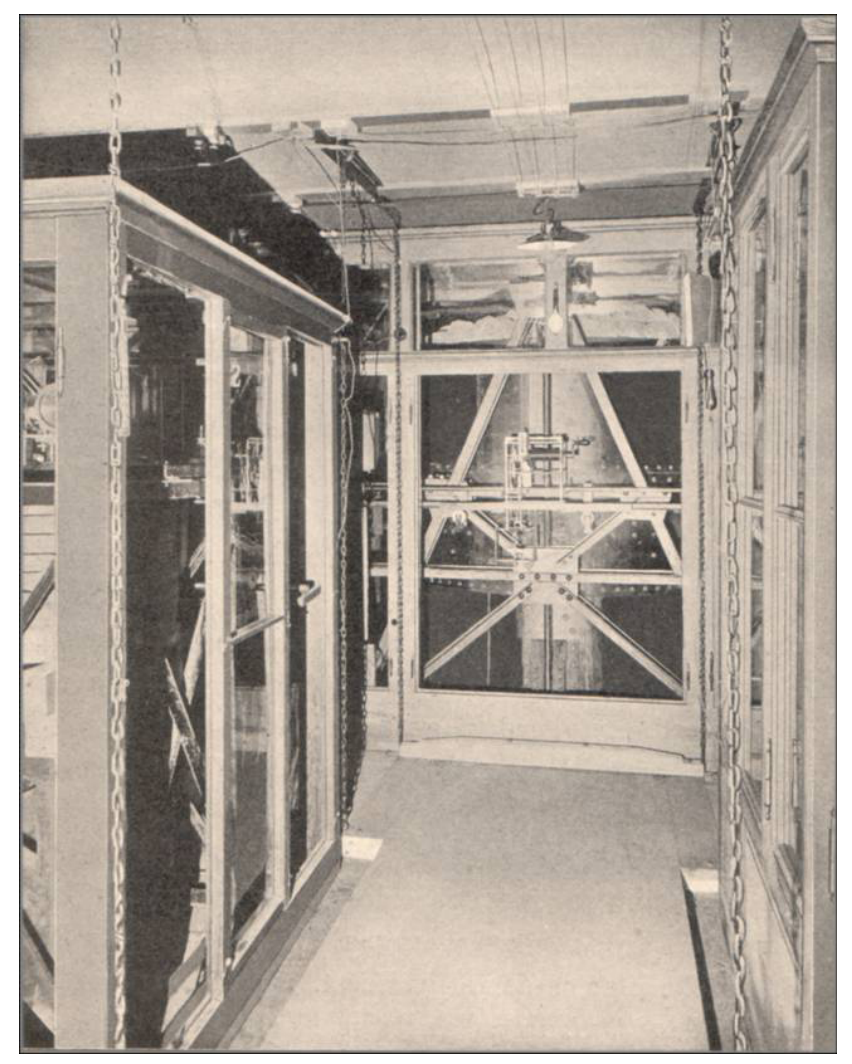

Figure 6. The seismograph room circa 1905. The suspension bridge to avoid stepping on the floor can be seen in the front. Undated picture taken from Wiechert (1906).

ponents for the horizontal seismograph, usually in the northsouth and east-west directions. The signal is then magnified 200 times by a mechanical lever system and written on an endless sheet of smoked paper (Fig. 5), which runs around a cylinder by a weight-driven clock (Wadsworth, 1942). Time marks are scratched on the paper every minute by lifting the writing index ("needle") off the paper (Wadsworth, 1942). The smoked paper is changed daily and the record is eventually fixed permanently by immersion in a solution of methylated spirit and shellac. The design of the vertical seismograph is different from the horizontal seismograph. A strong vertical spring is placed above a lever, where one arm is fixed to the framework and the free end holds the mass (Wadsworth, 1942). The signal is magnified 160 times and written to smoked paper as well (Wadsworth, 1942).

The instruments are very sensitive. For example, blowing against the huge cauldron of the $17 \mathrm{t}$ pendulum results in an immediate response of the needles. A person moving next to the pendulums or a change in the temperature of the room is visible in the records as well (Wiechert, 1906). Hence, in the beginning a so-called Hängebrücke (suspension bridge) was installed under the roof (Fig. 6) in order to prevent disturbances. Furthermore, due to ground noise induced by traffic, especially trucks and buses, the road in front of the institute's 


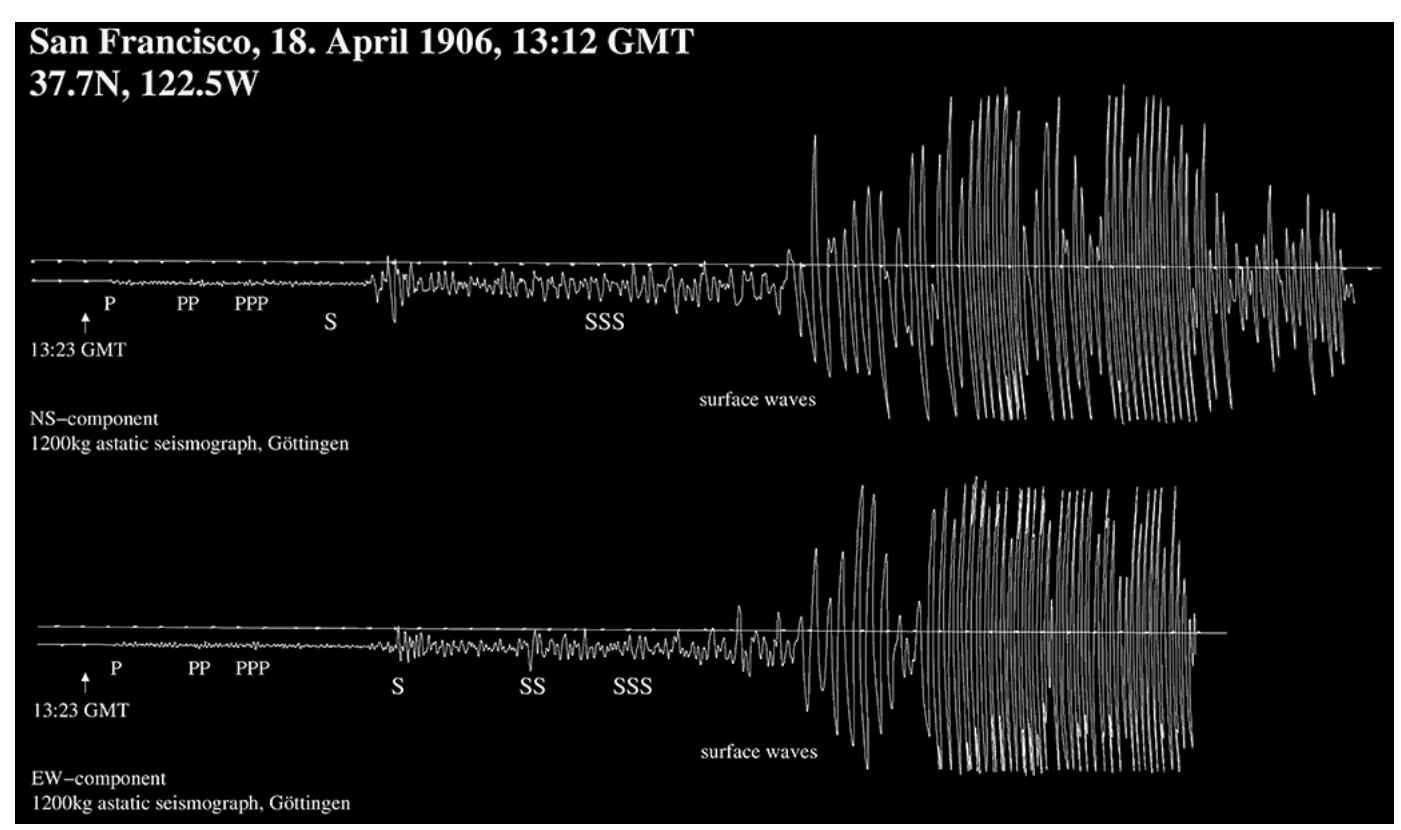

Figure 7. The record of the Great 1906 San Francisco earthquake with the astatic horizontal seismograph. Figure prepared and kindly provided by Elmar Rothert and Joachim Ritter.

area was and still is closed for cars above a weight of 2.5 tons (3.5 tons since 2010).

In 1902, the Gauß House was moved into the garden of the Institute of Geophysics in support of the geomagnetic investigations of the institute. It was originally built without iron in 1833/1834 at the ground of the astronomical observatory in Göttingen for earth-magnetic readings by Carl Friedrich Gauß (1777-1855) and Wilhelm Eduard Weber (1804-1891). Iron nails, for example, were substituted by copper nails to avoid disturbing influences from the iron on magnetic experiments. Magnetic measurements and calibrations of magnetic instruments such as the Göttingen borehole magnetometer (GBM; Virgil et al., 2010) were performed in the house.

\section{The first $100 \mathrm{yr}$ of observations}

The early years of the observatory were dominated by instrument development and stepwise extension of the number of observing instruments. In 1905, the institute became one of the main stations of the international network for earthquake research. In the following years astatic pendulums were installed all over the world and became standard instruments until World War II. The maximum number and individual types are difficult to estimate, but it is likely that more than 170 so-called Wiechert's were installed worldwide (see i.e. Duda et al., 1990).

In April 1906, the seismographs recorded the Great 1906 San Francisco earthquake (Fig. 7), one of the most significant earthquakes in the last century. This and other obser- vations show one great value of old seismograms recorded by the same instrument. Quantitative comparisons can be made, in this case between the 1906 and the 1989 Loma Prieta earthquake (Wald et al., 1993). Additional benefits are (Ritter, 2002) that the recordings contain important data to determine the spatial and temporal distribution of seismicity (Villaseñor et al., 1997), to reconstruct the focal mechanisms of major historical earthquakes (Wald et al., 1993) and to estimate seismic risk (Giardini, 1999).

In addition to the continuous observations in the Erdbebenhaus, further experiments were performed regarding near-surface geologic structures. For this purpose, Ludger Mintrop (1880-1956), since 1907 a student of Wiechert, dropped a steel ball of $4 \mathrm{t}$ weight and $1 \mathrm{~m}$ diameter (nowadays called Mintrop-Kugel (Mintrop ball)) from a $15 \mathrm{~m}$-high scaffold to generate small man-made earthquakes. The seismic waves were observed with portable seismographs. His experiments helped form the base for modern seismic exploration methods.

In the following years the institute became world-leading in the fields of seismology and seismics. Several methods and instruments were developed, discoveries made and patents filed and granted. However, it is beyond the scope of this paper to list all of them, and we refer to Siebert (1997) for more information. In view of the observatory, the discovery of the core-mantle boundary and its exact calculation at $2900 \mathrm{~km}$ depth by Beno Gutenberg (1889-1960) and the Wiechert-Herglotz method for the determination of the seismic velocity distribution of Earth's interior from the known 
propagation times of seismic waves may be highlighted as outstanding examples.

The First World War also affected the institute and some members served in the army. After the war it was important to unite the German scientists who worked in scientific isolation (Börngen et al., 1997). Thus, the German Seismological Society was founded in 1922 on the initiative of Wiechert. It was renamed in 1924 to the German Geophysical Society (Deutsche Geophysikalische Gesellschaft, DGG), as it is still known today.

The Erdbebenhaus was extended in 1925 with another building, the so-called neue Erdbebenhaus (new earthquake house). It housed additional seismographs and a calibration device.

Wiechert died on 18 March 1928, in Göttingen. Gustav Angenheister Sen. (1878-1945) became new director of the institute and observatory until shortly after the end of the Second World War. The war impeded a planned extension of the institute, which was eventually realized in 1970 with a new building in between the main building and the Erdbebenhaus. The research focus meanwhile changed back to geomagnetism, initiated by Julius Bartels (1899-1964) who became director in 1945. After his death in 1964, Manfred Siebert (1925-2013) became director of the institute. He held this position until 1992, two years after his retirement in 1990. He played an important role to save the observatory from demolition.

The last director was Ulrich Christensen (*1954) from 1992 until 2003. He then accepted a position as director at the Max Planck Institute for Aeronomy (now Solar System Research) in Katlenburg-Lindau. During this decade, the Erdbebenhaus hosted a seismometer and a modern mobile digital recorder during the Eifel Plume project (station A84) in 1998 (Keyser et al., 2002). The data of station A84 were also used for a check of the calibration of the Wiechert seismographs (Ritter, 2002). The recordings of the seismographs helped to analyze bomb explosions and seismic noise (e.g. Grevemeyer et al., 2000). Furthermore, the instruments were used for training students (e.g. calibration of instruments, seismic phase reading and earthquake localization, and history studies, see e.g. Ritter, 2001) and public relations. Since 2003 the director position has been vacant, however, the observations with the then $100 \mathrm{yr}$ old instruments have continued.

As with the Great 1906 San Francisco earthquake, all other major and/or well-known earthquakes of the 20th century have been observed. Among many others, full records of the 1923 Tokyo earthquake, the 1960 Valdivia earthquake or Great Chilean Earthquake, the 1964 Alaska earthquake, the 1971 San Fernando earthquake, the 1976 Friuli earthquake, the 1989 Loma Prieta earthquake and the 1992 Roermond earthquake have preserved.

\section{The relocation of the institute in 2005}

With the growth of the university over the years, and especially since the 1960s, space in the city of Göttingen became limited (Oberdiek, 2002). A new campus for sciences was developed north of Göttingen, where among other faculties the Faculty of Physics was placed in new buildings (Oberdiek, 2002). The Institute of Geophysics as part of the faculty was supposed to be moved in 2005 to the northern campus due to these activities. According to university plans, the old institute's buildings and ground were to be sold by the state of Lower Saxony, who was the owner of the property.

The status of the Erdbebenhaus and the other historic buildings remained unclear. The Institute of Geophysics was actually expecting to keep access to the Erdbebenhaus in the future and that only half of the area, including the two main buildings, would be sold. However, the director of the institute was informed in July 2004 that the complete grounds, including all buildings, would be sold. It was planned that only the Gauß House, already a cultural heritage, would be moved back to its original location in the city center. This meant that after more than $100 \mathrm{yr}$, all historic instruments would be out of reach for the institute in the future. As a final consequence, a dismantling of the observatory with the Wiechert seismographs as well as the Mintrop-Kugel was feared.

At the same time, a search was started to find a solution that fitted all interests. Three conditions had to be fulfilled according to the former director Manfred Siebert:

1. The Erdbebenhaus and its instruments will be preserved and maintained by the institute or another institution of the university. Reasonable costs for material and personal will be covered.

2. The future owner of the grounds will allow free entrance to the Erdbebenhaus for maintenance and occasional visits.

3. There will be free access to the magnetometer house (another historic building on the ground) to allow magnetic calibrations after relocation of the Gauß House to the city center.

The institute supported these conditions, however, it also noted that the institute on behalf of the university and its tight financial situation could not guarantee to bear the expenses. In the following weeks, first inquiries to the university and the City of Göttingen to protect the historic sites were answered unsatisfactorily: both the city and the university were unable and/or uninterested to save the ongoing observations and the observatory itself. The main reason were financial problems, and the university also announced that the observed data are unimportant for research. Both explanations led to disapproval by many colleagues in the world as (i) the Institute of Geophysics and thus the university was responsible for the observatory by its bylaws and (ii) it is indispensable in earthquake research to compare the systematics 
of major earthquakes from different time spans based on long records with the same instrument (see e.g. Wald et al., 1993; Grevemeyer et al., 2000). Letters of support to continue the operation of the Wiechert seismographs by the University of Göttingen were sent by researchers and the presidents of national and international research organizations. The Vice President of the university called for help from regional precision engineering companies. The local and regional press as well as the Frankfurter Allgemeine Zeitung (one of the leading daily German quality newspapers) reported about the unclear situation. Manfred Siebert gave interviews in radio and TV, and his daughter Ina Siebert launched, together with Eric Helmvoigt, a website about the Erdbebenwarte and its endangerment. Current and former members of the institute presented a poster at the 2nd General Assembly of the European Geosciences Union in 2005 (Siebert, 2005). However, no immediate help was offered following these activities.

\section{A new owner - Wiechert'sche Erdbebenwarte Göttingen e.V.}

On 24 August 2004, a meeting of the working group "Technology" of the Measurement Valley society took place at the institute. Measurement Valley is a union of more than 30 regional companies and institutions in the field of measurement technologies, and the university is one of its members. The working group holds bimonthly meetings at one of the members' locations, led by its chairman Wolfgang Brunk (*1952). It remains unclear if it was by accident or by purpose, but the meeting in August 2004 was hosted by the university in the Institute of Geophysics. Siebert introduced the institute and outlined the endangerment of the observatory. Impressed by the presentation as well as the instruments and their history, the working group decided that Measurement Valley shall make every effort to save the observatory.

The first step by Measurement Valley was to apply in September 2004 for monument protection at the Niedersächsisches Landesamt für Denkmalpflege (Lower Saxonian agency for heritage maintenance). In November, an immediate reply stated that not only the Erdbebenhaus, but all buildings including the instruments, are a cultural heritage and, thus, protected from demolition or remodeling. Measurement Valley further called for interested volunteers in maintaining the observatory.

After this first success, the state of Lower Saxony indicated that it would be possible to split the grounds into two parts, with one part containing the Erdbebenhaus. As the bylaws of Measurement Valley did not allow to buy it, it became clear that a new society had to be founded. Therefore, on 11 April 2005 the Wiechert'sche Erdbebenwarte Göttingen e.V. was founded as a registered society (e.V.) by 15 founding members with Wolfgang Brunk as new chairman. The main aims of the society are to continue the observation and the

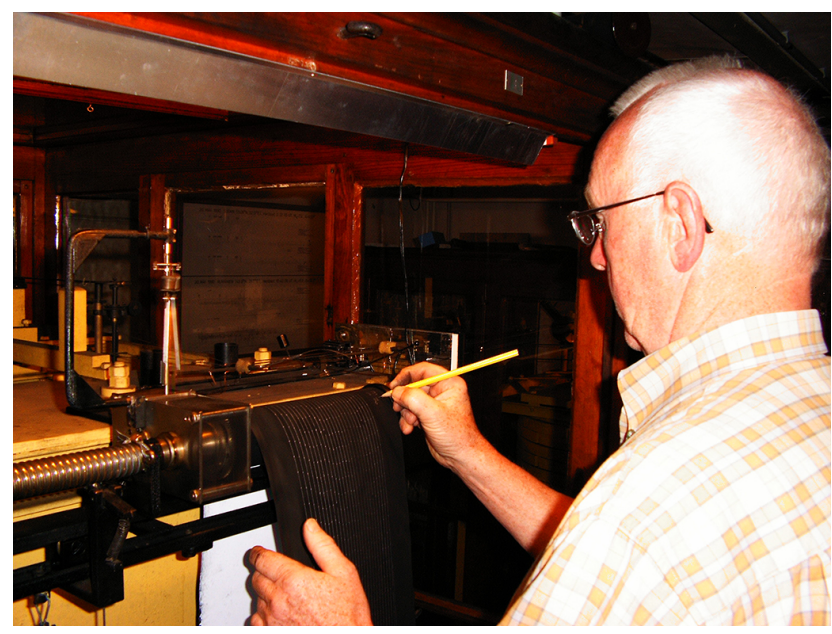

Figure 8. Removing the (second last) smoked paper from the seismographs on 16 June 2005. Photo: Holger Steffen.

scientific operation of the observatory and the other historical devices, as well as opening it to the public.

Discussions on which part of the grounds and which buildings should be included went on during this time. Several ideas came up and many questions, for example, if the Gauß House should be moved or not, needed an answer. Furthermore, the matter of who would buy the land was discussed: the City of Göttingen or the society? Who will take care of the trees? And many more. As all these details are beyond the scope of this paper, we refer the interested reader to Brunk et al. (2005) for more information. The final solution was to split the property in such a way that all historic buildings, including the Erdbebenhaus, the Gauß House, the magnetic hut, the Mintrop-Kugel and its scaffold, were included in one property of about $10000 \mathrm{~m}^{2}$, which was bought by the new society. All instruments and further movables in the buildings belong to the society as well. The contract was signed on 12 August 2005. Since 30 August 2005, the registered society is the owner. The other part of the grounds, including the old and new institute's building, was sold to Jugendhilfe Schloss Wollershausen, a youth welfare service. They established the Jugendhilfe Am Rohns in the now renovated buildings. In agreement with the new neighbor no fence separates the two properties to date.

During the activities of the new society in spring 2005, the institute prepared for the move to the new building. Observations with the instruments continued with the daily changing of the smoked paper. The society hoped that observations would continue until the instruments could be officially accessed and members of the society were trained in operation of the instruments. However, on 13 June 2005, two months before the society signed the contract, the institute's director ordered the last change of paper to be made on 16 June 2005 (Fig. 8), as all staff resources were needed for the move. Institute members filed for continuation in a last-minute institute 
meeting, but it was rejected by the professors. However, it was agreed that the institute's staff would help the society in operating the instruments from July on until the end of August. Thus, on 17 June 2005, more than $100 \mathrm{yr}$ of almost continuous observations ended. It was unclear that day if the fragile mechanics of the instruments could be reactivated a few weeks later by the society.

\section{Activities since 2005}

On the same day (17 June 2005), the society got all keys to the buildings it was about to buy in a few weeks. This led to the somewhat strange situation that the society was now responsible for all buildings and instruments without even having finished negotiations with the state of Lower Saxony, the City of Göttingen and the university. Nonetheless, from 27 June 2005 on the society worked on the reactivation of the instruments, which was finally arranged on 1 July 2005 with the volunteering help of institute members. However, the vertical seismograph was not functioning until 10 July 2005. Moreover, the horizontal seismograph had continuous problems (sudden stops of observations) until end of July due to bearing damage after the shutdown. It was finally repaired with the help of a local horologist and has been continuously observing again since 16 October 2005.

It became clear after the repair that a continuous operation as before cannot be mastered by the society. Therefore, an optic-digital sensor system was installed in December 2005 and spring 2006 on top of all seismographs for continuous recording. This employs the old mechanisms, but recording is now directly enabled with a computer instead of smoked paper. The latter can still be used for public demonstrations. The first earthquake recorded both on smoked paper and digitally occurred on 2 January 2006, east of the South Sandwich Islands. It had a magnitude of 7.4 at a depth of $10 \mathrm{~km}$ and was recorded with the astatic horizontal seismograph.

Scientific evaluation is now possible due to this upgrade. For example, when comparing records of one of the old seismographs to modern seismometers. In cooperation with the Federal Institute for Geosciences and Natural Resources (BGR), a sensitive Streckeisen STS-2 broadband seismometer was installed on 18 January 2006 in the building as well. The station code is GTTG and it serves as a station of the German Regional Seismic Network with open data access. Since then, all major earthquakes, such as the Tōhoku earthquake on 11 March 2011 (Fig. 9), have been digitally recorded with both the STS-2 and the Wiechert seismographs. It is hoped that this will enable and ease future scientific investigations, e.g. as the old recordings represent the only quantitative measure of seismicity during the first half of the 20th century (Ritter, 2002) they can be much better interpreted now when studying and comparing the latest records of both instrument generations.

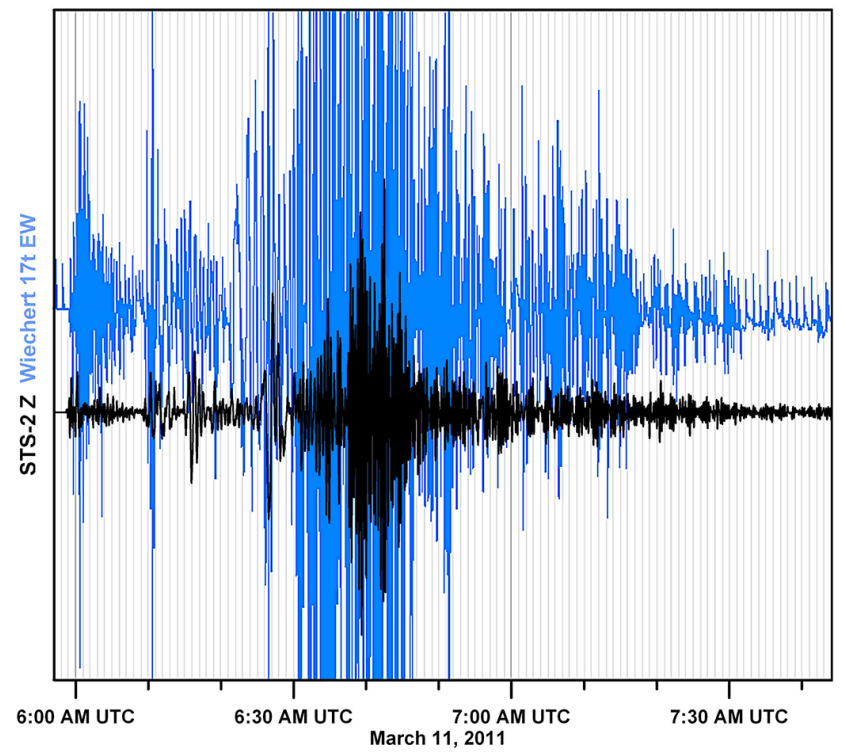

Figure 9. Example: record of the 11 March 2011 Tōhoku earthquake as observed with the vertical $(Z)$ component of the Streckeisen STS-2 seismometer (black) in the Erdbebenwarte (Station GTTG) and the east-west (EW) component of the $17 \mathrm{t}$ horizontal seismograph (blue). Offset between graphs for visibility. No further scientific processing is applied to the data.

The first public opening with guided tours was announced for 5 March 2006. Despite snow and cold weather conditions, the society welcomed more than 200 visitors. Several tours were held in the afternoon presenting the instruments and their history. A demonstration of fixing smoked paper was shown as well. Members answered hundreds of questions by the interested audience.

Several thousand people have visited the observatory since then. The observatory is usually open to the public every first Sunday of the month. In addition, open house events are hosted every second summer, and additional guided tours can be booked. About 50 tours per year are made now.

The first highlight for the society was the selection of the observatory as landmark in the competition "Germany - Land of Ideas" (Brunk et al., 2005; Rudloff et al., 2006). In view of the 2006 FIFA World Cup this initiative presented the inventiveness and creative passion in Germany for a selected landmark. The patron was the German president Horst Köhler. On 21 August 2006, the society invited the world to come to celebrate the Erdbebenwarte. For this event, the Gauß House, as well as other buildings were renovated. In addition, the Mintrop-Kugel and the scaffold were modernized with financial support of the Robert Bosch Foundation. Man-made earthquakes were generated exactly $98 \mathrm{yr}$ after the first drop (Meyer, 1974) during the event. In the following years, further modernizations such as an automatic release of the ball and a hut for the winch were installed (Brunk, 2008, Fig. 10). The Mintrop-Kugel meanwhile drops about $15.5 \mathrm{~m}$. 


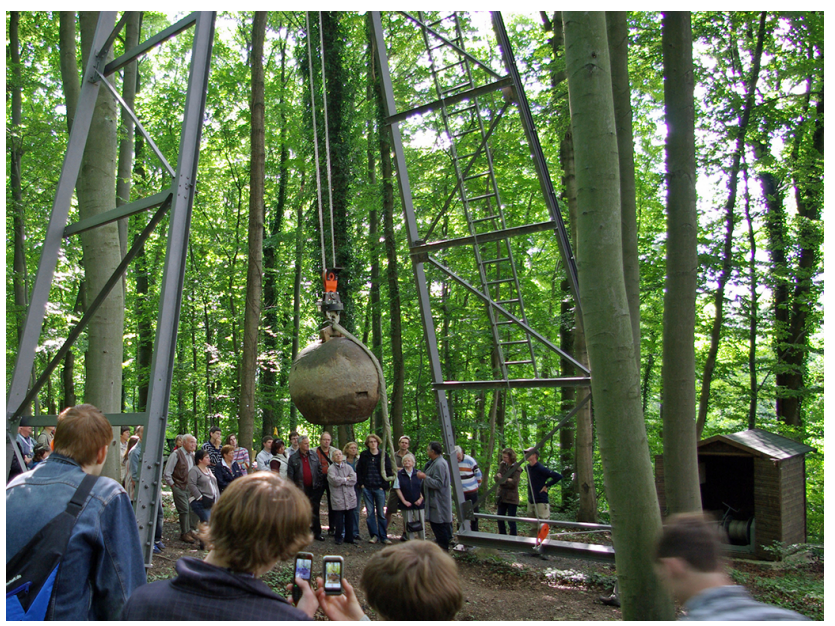

Figure 10. Preparation of the fall from about $14.5 \mathrm{~m}$ above surface of the Mintrop-Kugel with a weight of $4 t$ during a public tour in September 2010. Wolfgang Brunk (center next to the scaffold) explains the experiment to the interested audience. The hut with the winch can be seen to the right. Photo: Udo Wedeken.

It is released at a height of about $14.5 \mathrm{~m}$ of the scaffold into a $1.5 \mathrm{~m}$ deep hole in the surface. This hole developed during the years due to the drop experiments.

Besides these major activities the society continuously improves the exhibition, which shows the history of geophysics, seismology and geomagnetics in Göttingen. Among other things the society is in possession of a replica of the GaußWeber telegraph, as well as the experiment by Gauß to measure Earth's magnetic field.

In Spring 2008, four big boxes of the inheritance of Ludger Mintrop were offered to the society (Brunk and Steffen, 2008). They contained thousands of documents. Personal documents were given to the Mintrop family, and the remaining ones were eventually forwarded to the history working group of the German Geophysical Society, which is a member of the Wiechert'sche Erdbebenwarte Göttingen e.V.

On November 2011, a stamp was issued by the German Ministry of Finance in honor of Wiechert's 150th birthday on 26 December 2011. The stamp features the picture of Emil Wiechert from Fig. 1 and the record of the San Francisco earthquake from Fig. 7. It clearly demonstrates that Wiechert and his Erdbebenwarte are remembered in the German public.

On 12 August 2013, the website http://www. erdbebenwarte.de was relaunched with a new design. It contains a tremendous amount of interesting material about the history of the Erdbebenwarte, its instruments and related people, recent earthquake observations, activities of the society, and much more.

\section{Final remarks and outlook}

The detailed investigation of the physical structure of the Earth with the help of seismic waves started in 1902 in Göttingen due to new instruments and, in combination with, new mathematical methods developed at the institute. Hence, the Wiechert'sche Erdbebenwarte is associated with the beginning of modern seismology. The society will keep the memory alive about its importance and it will maintain the instruments and historic buildings. Open houses and interesting and cheerfully guided tours will remain in the program. Moreover, the society continues observations with the historic, but still functioning instruments. This will add, hopefully, several hundreds of years more to the already impressive long record of $111 \mathrm{yr}$, and to compare the characteristics of earthquakes around the world. This is further eased by digital recording and the STS-2 seismometer installed nearby.

The society looks forward to any new member or supporters. Main facts about the society and the observatory can be found online at http://www.erdbebenwarte.de.

Acknowledgements. We would like to thank the editors, Kristian Schlegel and Jaime Urrutia-Fucugauchi, for their assistance as well as the reviewers, Joachim Ritter, Udo Barckhausen and Cinna Lomnitz, for their constructive and helpful reviews. We are grateful for additional comments by Christopher Juhlin and Rebekka Steffen (Uppsala University). We would also like to thank all supporters, personally or financially, of the Erdbebenwarte in the last years. Special thanks go to late honorary member of the society Manfred Siebert for his efforts and fruitful discussions over the years, as well as his daughter Ina Siebert and Eric Helmvoigt for maintaining the website over the last decade.

Edited by: J. Urrutia-Fucugauchi

Reviewed by: J. R. R. Ritter, U. Barckhausen, and C. Lomnitz

\section{References}

Börngen, M., Homilius, J., and Jacobs, F.: Die Deutsche Geophysikalische Gesellschaft, 1922-1997, in: Zur Geschichte der Geophysik in Deutschland (Jubiläumsschrift der DGG), edited by: Neunhöfer, H., Börngen, M., Junge, A., and Schweitzer, J., 7-26, Deut. Geophys. Ges., Hamburg, 1997 (in German).

Brunk, W.: Mintrop-Kugel fällt wieder an der Wiechert'schen Erdbebenwarte, Mitt. Deut. Geophys. Ges., 3/2008, 19-20, 2008 (in German).

Brunk, W. and Steffen, H.: Nachlass von Ludger Mintrop aufgetaucht - eine unglaubliche Fundgrube nun im Besitz des Vereins Wiechert'sche Erdbebenwarte Göttingen e.V., Mitt. Deut. Geophys. Ges., 2/2008, p. 37, 2008 (in German).

Brunk, W., Leven, M., and Steffen, H.: Über Stock und Stein - die Rettung der Göttinger Erdbebenwarte durch den Verein "Wiechert'sche Erdbebenwarte e.V.", Mitt. Deut. Geophys. Ges. 4/2005, 17-30, 2005 (in German).

Duda, S. J., Khattri, K. N., Purcaru, G., and Schick, R.: WiechertSeismograms of the Göttingen Observatory Microfilming and Reinterpretation, Gerl. Beitr. Geophys., 99, 313-336, 1990. 
Giardini, D.: The global seismic hazard assessment program (GSHAP) 1992/1999, Ann. Geofis., 42, 957-974, 1999.

Grevemeyer, I., Herber, R., and Essen, H.-H.: Microseismological evidence for a changing wave climate in the northeast Atlantic Ocean, Nature, 408, 349-352, doi:10.1038/35042558, 2000.

Gutenberg, B.: Geh. Reg.-Rat Prof. Dr. E. Wiechert †. Meteorologische Zeitschrift 45, Kleine Mitt., 183-185, 1928 (in German).

Hennings, R. and Ritter, J. R. R.: Bibliography of Emil Wiechert, in: IASPEI International Handbook of Earthquake and Engineering Seismology, Part B, Chapter 79.24, edited by: Lee, W. H. K., Kanamori, H., Jennings, P. C., and Kisslinger, C., 30-33, Academic Press, 2003.

Keyser, M., Ritter, J. R. R., and Jordan, M.: 3D shear-wave velocity structure of the Eifel plume, Germany, Earth Planet. Sc. Lett., 203, 59-82, doi:10.1016/S0012-821X(02)00861-0, 2002.

Meyer, J.: Künstliche Bodenerschütterungen mit der Mintrop Kugel, in: Zur Geschichte der Geophysik, edited by: Birett, H., Helbig, K., Kertz, W., and Schmucker, U., 67-71, Springer, Berlin Heidelberg New York, 1974 (in German).

Mulligan, J. F.: Emil Wiechert (1861-1928): Esteemed seismologist, forgotten physicist, Am. J. Phys., 69, 277-287, doi:10.1119/1.1323962, 2001.

Oberdiek, A.: Göttinger Universitätsbauten - Die Baugeschichte der Georg-August-Universität. 2. Auflage, Göttinger Tageblatt GmbH \& Co KG, Göttingen, 228 pp., 2002 (in German).

Ritter, J. R. R.: Students explore history of the Göttingen Institute for Geophysics, Eos Trans. AGU, 82, 224-224, doi:10.1029/01EO00123, 2001.

Ritter, J. R. R.: On the recording characteristics of the original Wiechert seismographs at Göttingen (Germany), J. Seismol., 6, 477-486, doi:10.1023/A:1021101116511, 2002.

Rudloff, A., Steffen, H., and Wedeken, U.: Wiechert'sche Erdbebenwarte als "Ort im Land der Ideen" ausgezeichnet, Mitt. Deut. Geophys. Ges., 3/2006, 24-25, 2006 (in German).

Schreiber, H.: Historische Gegenstände und Instrumente im Institut für Geophysik der Universität Göttingen, Ein Katalog, Akademie der Wissenschaften zu Göttingen, Kommission für historische Apparate, Göttingen, 48 pp., 2000 (in German).

Schröder, W.: Emil Wiechert und seine Bedeutung für die Entwicklung der Geophysik zur exakten Wissenschaft, Archive for History of Exact Sciences, 27, 369-389, 1982 (in German)
Schweitzer, J.: Chapter 79.24, Part A: Early German contributions to modern seismology, in: IASPEI International Handbook of Earthquake and Engineering Seismology, Part B, edited by: Lee, W. H. K., Kanamori, H., Jennings, P. C., and Kisslinger C., Academic Press, 2003.

Siebert, M.: Geschichte des Instituts für Geophysik in Göttingen, in: Zur Geschichte der Geophysik in Deutschland (Jubiläumsschrift der DGG), edited by: Neunhöfer, H., Börngen, M., Junge, A., and Schweitzer, J., 107-114, Deut. Geophys. Ges., Hamburg, 1997 (in German).

Siebert, M.: The historical Wiechert Seismographs of Göttingen - an endangered cultural monument, Geophys. Res. Abstr., 7, 03944, 2005.

Villaseñor, A., Bergman, E. A., Boyd, T. M., Engdahl, E. R., Frazier, W. D., Harden, M. M., Orth, J. L., Parkes, R. L., and Shedlock, K. M.: Toward a comprehensive catalog of global historical seismicity, EOS Trans. AGU, 78, pages 581, 583 and 588, 1997.

Virgil, C., Hördt, A., Klein, T., Kück, J., Leven, M., and Steveling, E.: High-Precision Orientation of ThreeComponent Magnetic Downhole Logs, Sci. Dril., 9, 37-40, doi:10.2204/iodp.sd.9.07.2010, 2010.

Wadsworth, J.: The Wiechert Vertical Seismograph: An Improved Design, Geophys. J. Int., 5, 48-53, doi:10.1111/j.1365246X.1942.tb00445.x, 1942

Wald, D. J., Kanamori, H., Helmberger, D. V., and Heaton, T. H.: Source Study of the 1906 San Francisco Earthquake, B. Seismol. Soc. Am., 83, 981-1019, 1993.

Wiechert, E.: Über die Beschaffenheit des Erdinnern, Sitz.-Ber. Physik.-ökonom. Ges. Königsberg 37, 4, 1896 (in German).

Wiechert, E.: Theorie der automatischen Seismographen. Abhand. Königl. Ges. Wiss. zu Göttingen, Mathemat.-phys. Klasse 2 (Neue Folge), Nr. 1, 3-128, 1903 (in German).

Wiechert, E.: Das Institut für Geophysik der Universität Göttingen, in: Die Physikalischen Institute der Universität Göttingen - Festschrift im Anschlusse an die Einweihung der Neubauten am 9. Dezember 1905, edited by: Göttinger Vereinigung zur Förderung der Angewandten Physik und Mathematik, Universität Göttingen, 119-188, Teubner, Leipzig and Berlin, 1906 (in German). 